\title{
Early reserve effects linked to small home ranges of a commercial fish, Diplodus sargus, Sparidae
}

\author{
David Abecasis ${ }^{1, *, * *}$, Bárbara Horta e Costa ${ }^{1,2, * *}$, Pedro Afonso ${ }^{3,4}$, \\ Emanuel J. Gonçalves ${ }^{2}$, Karim Erzini ${ }^{1}$ \\ ${ }^{1}$ Centre of Marine Sciences (CCMAR), University of the Algarve, Campus de Gambelas, 8005-139 Faro, Portugal
${ }^{2}$ MARE - Marine and Environmental Sciences Centre, ISPA - Instituto Universitário, R. Jardim do Tabaco 34, 1149-041 Lisboa,
Portugal \\ ${ }^{3}$ Institute of Marine Research, Department of Oceanography and Fisheries, University of the Azores, 9901-862 Horta, Portugal \\ ${ }^{4}$ LARSYS - Laboratory of Robotics and Systems in Engineering and Science, Avenida Rovisco Pais, 1, 1049-001 Lisboa, Portugal
}

\begin{abstract}
Studies that combine both the ecological responses of marine species and protection measures with movement patterns and habitat use are of major importance in order to better understand the performance of marine protected areas (MPA) and how species respond to their implementation. However, few studies have assessed MPA performance by relating local individual movement patterns and the observed reserve effects. In this study, we combined acoustic telemetry with abundance estimates to study the early effects of a recently established small coastal MPA on the local populations of white seabream. The results show that even small, recently established coastal MPAs can increase the abundance and biomass of commercial fish species, provided that target species have small home ranges and exhibit high site fidelity.
\end{abstract}

KEY WORDS: Marine reserve $\cdot$ Monitoring $\cdot$ Acoustic telemetry $\cdot$ Underwater visual census

\section{INTRODUCTION}

Marine protected areas (MPAs) have been widely implemented throughout the world as tools to protect biodiversity and/or manage fisheries (Botsford et al. 2009). Due to the limitation of fishing activities within MPAs, and especially inside no-take MPAs (marine reserves), the expected beneficial effects include an increase in biodiversity, abundance, and individual size of marine species, especially those targeted by fisheries (Russ 2002, Tetreault \& Ambrose 2007, Lester et al. 2009, Hamilton et al. 2010). Because these effects are expected to translate into an exponential increase in potential fecundity, and subsequently in potential production of larvae, MPAs may contribute to the replenishment of populations outside the protected areas through larval dispersal mechanisms (Tetreault \& Ambrose 2007, Pelc et al.
2010, Fraschetti et al. 2011) and through the densitydependent export of juvenile and adult biomass (i.e. spillover) (Kramer \& Chapman 1999, Russ 2002). Combined, these mechanisms can contribute to the recovery and sustainable exploitation of populations by generating an increased net benefit (Vandeperre et al. 2011).

A recent review concluded that MPA performance is dependent on MPA size (Claudet et al. 2008). This is largely seen as an effect of the species' spatial ecology, because very small reserves may fail to encompass all of the essential habitat and individual home ranges of local populations, leading to only partial protection of the daily or seasonal range of most targeted species (Kramer \& Chapman 1999, Abecasis et al. 2013a). Despite this limitation, small reserves have resulted in large increases in individual fish size, especially for sedentary commercial species 
(Tetreault \& Ambrose 2007, Claudet et al. 2008, Lester et al. 2009), since most of their home range is thought to be included within these areas (Kramer \& Chapman 1999). In addition, some demersal vagile species forming 'facultative schools' have also demonstrated positive responses with respect to density when protected (Claudet et al. 2010).

Information about habitat preference, movement patterns and home range areas is vital in order to understand species' responses to protection measures and should be taken in account when designing the location and spacing of MPAs (Botsford et al. 2003, Claudet et al. 2008, Grüss et al. 2011, Babcock et al. 2012). Although the magnitude of responses is expected to differ between species according to their ecology and behaviour, few studies have assessed MPA performance in relation to fish traits (but see Claudet et al. 2010), and even fewer have compared local home range areas and movement patterns with the concomitant reserve effects (but see Meyer \& Holland 2005, Abecasis et al. 2013a, 2014a). Fish traits and mobility vary within species and even among geographical areas (e.g. Abecasis et al. 2008, 2012, 2013b). Thus, observed local patterns of species movements may allow a more accurate interpretation of the protection effects within and surrounding MPAs, especially when a lack of information from the period before MPA implementation prevents the use of Before-After-Control-Impact (BACI) analysis (Osenberg et al. 2011).

In this study, we combined a telemetric study with abundance estimates from underwater visual surveys to investigate the effects of the implementation of the Luiz Saldanha Marine Park (a multiple-use MPA with 3 different protection levels) on local populations of white seabream Diplodus sargus (Linnaeus, 1758). Specifically, we tested whether white seabream (1) show high annual site fidelity, (2) utilize home ranges small enough to be contained within the reserve units, and (3) show an increase in abundance and biomass in the marine reserve compared to the buffer area.

\section{MATERIALS AND METHODS}

\section{Study species}

The white seabream is a demersal fish species that usually occurs in non-obligatory schools associated with rocky and mixed habitats (Claudet et al. 2010). It is one of the most important species for small-scale commercial and recreational fisheries in southern
Europe (Veiga et al. 2010). Movements and activity patterns, habitat use and site fidelity have been studied in adults and juveniles using tag-recapture and acoustic telemetry techniques (Abecasis et al. 2009, 2013b, Lino et al. 2009, D'Anna et al. 2011, Koeck et al. 2013). After a strong ontogenetic migration by juveniles when they leave estuarine nurseries to join coastal reefs (Abecasis et al. 2009), white seabream demonstrate high site fidelity to their rocky reef habitats (D'Anna et al. 2011, Abecasis et al. 2013b). The average size of an adult seabream home range varies from $0.11 \mathrm{~km}^{2}$ in the Mediterranean (D'Anna et al. 2011) to $1.88 \mathrm{~km}^{2}$ in south Portugal (Abecasis et al. 2013b). Such intraspecific variability highlights the need for local studies across the species' range.

\section{Study area}

This study took place in the Luiz Saldanha Marine Park (LSMP), a $53 \mathrm{~km}^{2}$ marine park that stretches over $38 \mathrm{~km}$ of Portuguese coastline (Fig. 1A). The main habitats in the park include nearshore shallow rocky reefs and shallow rocky outcrops, with sandy bottoms covering the majority of the park from shallow to deeper areas, where muddy bottoms dominate (Horta e Costa et al. 2013a). The management plan, approved and implemented gradually starting in mid-2005, defines 3 different protection levels (Fig. 1B): one fully protected area (FPA; $4.2 \mathrm{~km}^{2}$ in area); 4 partially protected areas (PPAs; totalling $21 \mathrm{~km}^{2}$ ); and 2 buffer areas (BAs; totalling $28 \mathrm{~km}^{2}$ ). The FPA is a no-take, no-access area (except for research, monitoring and education purposes) and is therefore considered a marine reserve. Local commercial fishing with traps and jigs is allowed in the PPAs (except in PPA 1, where no extractive uses are permitted) but only beyond $200 \mathrm{~m}$ from the shoreline. In the BAs, fishing vessels smaller than $7 \mathrm{~m}$ in length and recreational angling activities are allowed. Commercial diving for bivalves or other marine organisms, spearfishing, trawling and purse seining are forbidden throughout the park. Only commercial fishers from Sesimbra (a town located within the LSMP) have licenses to operate within the park. Due to the strong local fishing traditions and dependence on fishing in Sesimbra, the different protection measures were implemented gradually. The PPAs were implemented in 2006 (the FPA started as a PPA), and zoning was completed in mid-2009 (Horta e Costa et al. 2013a). Surveillance and enforcement by park rangers and the maritime police started immediately after implementation of the management plan. 


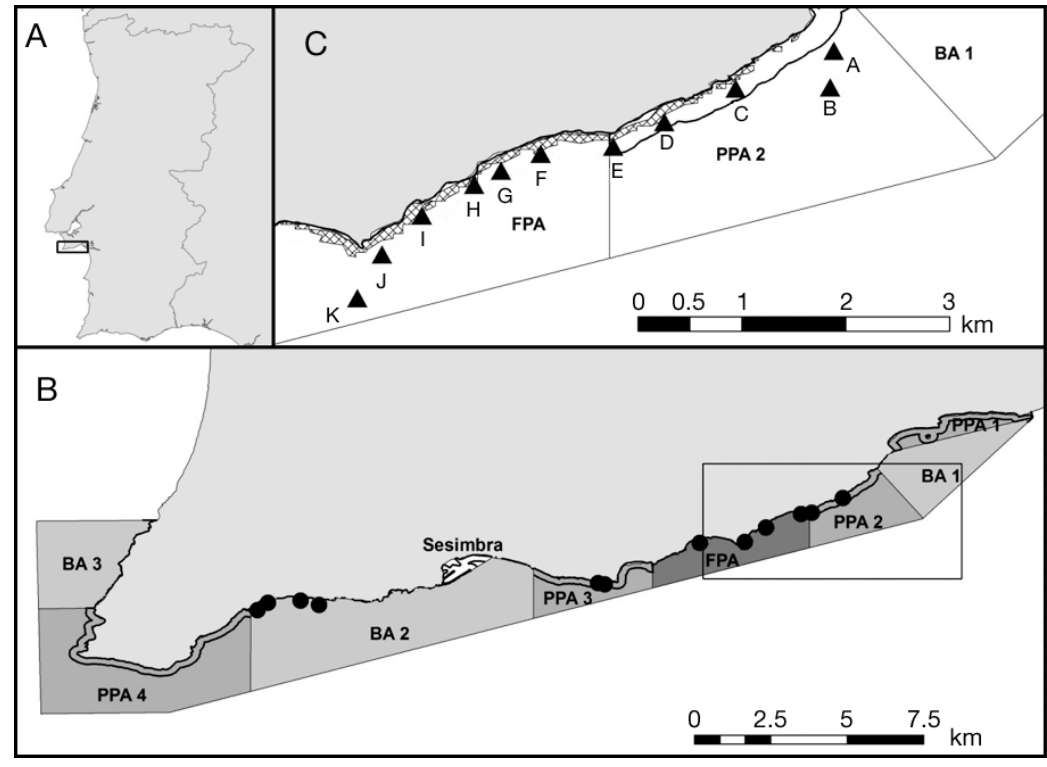

Fig. 1. Location of (A) the Luiz Saldanha Marine Park, Portugal, and (B) its zoning map showing the fully protected area (FPA), partially protected areas (PPA 1 to 4), and buffer areas (BA 1 to 3). Black dots: underwater visual census (UVC) sites (outside the reserve: 4 sites in BA 2; inside the reserve: 4 sites in PPAs 2 and 3, and 4 sites in the FPA); (C) triangles: acoustic receiver locations (denoted A-K); hatched area: rocky reef. Solid black line represents the $200 \mathrm{~m}$ from the coastline limit

\section{Fish counts}

Underwater visual census (UVC) on the rocky reef fish assemblage were conducted by 3 trained divers who recorded the species, number and individual size of mobile fishes using the $65 \mathrm{~m}$ strip transect methodology described in Horta e Costa et al. (2013b). Four fixed stations were consecutively sampled in each of the 3 levels of protection during spring and autumn of 2009 and 2010. Four transects were performed in each station, totalling 192 replicates (48 per season per year) (Fig. 1B).

\section{Acoustic telemetry}

Fish were captured in May and June 2011 and May and October 2012, using hook and line baited with shrimp. Twenty white seabream were fitted with an acoustic transmitter. Tagged fish ranged between 20 and $37 \mathrm{~cm}$ in total length (TL), which correspond to fish between 3 and 13 yr old (Abecasis et al. 2008). We used Vemco transmitters: V7 $(7 \mathrm{~mm}$ diam.) with an expected lifetime of $95 \mathrm{~d}$, V9 (9 mm diam.) with an expected lifetime of $151 \mathrm{~d}$ and V9 with expected lifetime of $282 \mathrm{~d}$ (see Table 1). Fish were placed inverted into a V-shaped cradle, and acoustic transmitters were introduced into the coelomic cavity through an incision in the ventral line between the insertion of the pectoral fins and the anus (Abecasis \& Erzini 2008). No anaesthesia was used. The incision was closed using cyanoacrylate tissue adhesive (Vetseal, BBraun). The overall procedure took less than 2 min. Fish were kept in a small onboard tank until normal breathing rates and swimming behaviour were observed. Fish were released at the same location as they had been captured (within the monitored area) 15 min after capture.

An area of $\sim 4.8 \mathrm{~km}$ of coastline covered by an array of 11 acoustic receivers (VR2 and VR2W, Vemco) placed in a line parallel to the coast was monitored to detect the presence of tagged fish (Fig. 1C). Preliminary tests run for more than $1 \mathrm{wk}$ in duration, under varying sea conditions, showed detection ranges of approximately $300 \mathrm{~m}$ for V9 transmitters and $100 \mathrm{~m}$ for V7 transmitters. In addition, no significant differences were found between the number of detections during day or night.

Although the monitoring period lasted from 1 May 2011 until 2 July 2013, 1 receiver (Fig. 1C: receiver H) became non-operational after 24 December 2012. On average, the receivers were cleaned of incrusting algae and fauna and data was downloaded every 3 mo.

\section{Data analyses}

Since (1) fishing in the PPAs is prohibited within $200 \mathrm{~m}$ from shore, (2) the rocky reef is well contained within this distance for most of the park, including the full extent of PPAs 2 and 3, and (3) no netting or hook-and-line fishing is allowed inside the PPAs, we considered both the FPA and the PPAs as reserves $\left(\mathrm{PPA} 2+\mathrm{PPA} 3=6.8 \mathrm{~km}^{2}\right.$ and FPA $=4.2 \mathrm{~km}^{2}$; total reserve area $=11 \mathrm{~km}^{2}$ ). The reserve areas were then compared to fished areas (BA $2=16.1 \mathrm{~km}^{2}$ ) (Fig. 1B). As in Horta e Costa et al. (2013b), an unbalanced design was followed by comparing 8 sites from the reserve ( 4 from each FPA and PPA) with 4 sites from the fished area. All sites were considered to have similar habitats.

The UVC data for white seabream larger than legal size $(15 \mathrm{~cm}$ TL) were analysed to test for an effect of 
protection, which would be shown as an increase in fish density and/or biomass inside the reserve when compared to fished areas. The response variable 'density' refers to the abundance in numbers $\mathrm{m}^{-2}$. Length $(L)$ was transformed to weight $(W)$ using the $L-W$ relationship for white seabream (Gonçalves et al. 1997). Biomass was then calculated by multiplying abundance and individual weight. The response of white seabream to protection was evaluated by comparing the average responses of the variables biomass $\left(\mathrm{g} \mathrm{m}^{-2}\right)$ and density (no. $\mathrm{m}^{-2}$ ) from all sites inside the reserve (In) with the average responses (Av) from all sites outside the reserve (Out), through the logarithm of the response ratios, $\mathrm{LnRR}_{\text {InOut }}=\mathrm{Ln}(\mathrm{AvIn} /$ AvOut), for both biomass and density response variables (Hamilton et al. 2010). This was repeated for each season and year $(\mathrm{Y} 1 \mathrm{~S} 1=2009$ Spring; $\mathrm{Y} 1 \mathrm{~S} 2=$ 2009 Autumn; Y2S1 = 2010 Spring; Y2S2 $=2010$ Autumn). The average of the logarithms of In/Out response ratios were calculated, resulting in the average ratio of the 4 independent sampling events, $A v L n R R_{\text {InOut }}=A v L n R R_{\text {InOut }} i$, where $i$ is the index for the 4 YearSeason, YS. The respective standard error was then calculated as $\mathrm{SE}=\mathrm{SD}\left(\operatorname{LnRR}_{\text {InOut }} \mathrm{i}\right) / \operatorname{sqrt}(4)$ (Hamilton et al. 2010).

Moreover, the response of white seabream to the FPA vs. adjacent PPAs was also evaluated to test whether the PPAs can actually function as a reserve (no-take) for white seabream and be compared together (FPA and PPAs as inside reserve) to the outside area (as done in the In/Out comparison). Thus, the average responses of the variables from all sites in the FPA were compared to the average responses from all sites in the PPAs, through similar log response ratios, $\mathrm{LnRR}_{\mathrm{FPAPPA}}=\mathrm{Ln}(\mathrm{AvFPA} / \mathrm{AvPPA})$, for both biomass and density for each of the 4 sampling events. The average of the 4 logarithms of FPA/PPA response ratios was also calculated, as well as the respective standard error: AvLnRR $\mathrm{FPAPPA}=\mathrm{Av}(\mathrm{LnR}-$ $\left.\mathrm{R}_{\mathrm{FPAPA}} i\right)$, where $i$ is the index for the $4 \mathrm{YS}$; $\mathrm{SE}=$ $\mathrm{SD}\left(\operatorname{LnRR}_{\mathrm{FPAPPA}} \mathrm{i}\right) / \mathrm{sqrt}(4)$.

Log ratios $>0$ indicate higher density or biomass inside the reserve relative to outside, or inside the FPA relative to the PPAs, whereas the opposite is the case for $\log$ ratios $<0$. The significance of the obtained ratios was tested through the comparison of the average log ratios to the $95 \%$ confidence intervals (CI), and they were considered significantly different from the null expectation of zero if the upper (AvLnRR + SE) or lower (AvLnRR - SE) limits consistently fell above or below zero. Data and limits were back transformed for plotting. In this situation, average response ratios $>1$ indicate higher density or biomass inside the re- serve relative to outside, or inside the FPA relative to the PPAs, whereas the opposite is the case for ratios $<1$ (R Development Core Team 2012).

Acoustic detections of tagged white seabream were managed using the VUE database (Vemco). Site fidelity was analysed using 2 different indices: the residency index $\left(I_{R}\right)$ proposed by Afonso et al. (2008) and the weighted residency index $\left(I_{\mathrm{WR}}\right)$ as in Abecasis et al. (2013b). The $I_{R}$ was estimated by dividing the total number of days a fish was detected by the number of days between the date of release and the last detection. This index was estimated for each receiver and for the entire array. The $I_{\mathrm{WR}}$ takes in consideration the expected lifetime of the transmitter (or study duration) and is calculated as follows:

$$
I_{\mathrm{WR}}=\frac{D_{\mathrm{d}}}{D_{t}} \times \frac{D_{i}}{D_{t}}
$$

where $D_{\mathrm{d}}$ is the total number of days a fish was detected, $D_{i}$ is the number of days between first and last detections and $D_{t}$ is the expected duration (time) of the acoustic transmitter or study duration, whichever is shorter. Both these indices vary between 0 (no residency) and 1 (full time resident). However, in cases where the number of days between the first and last detection exceeds the estimated lifetime of the transmitter, the $I_{\mathrm{WR}}$ can reach values higher than 1 .

Home range areas were calculated using the kernel utilization distribution (KUD). The KUD is a 2-dimensional probabilistic function that estimates the area of probability of finding a fish (Worton 1989). The KUDs were estimated based on centre of activity positions (COA). These COAs were calculated for each fish for 30 min periods using the method described by Simpfendorfer et al. (2002). This method uses presence data from multiple receivers and converts them to position estimates based on weighted means of the number of detections at each receiver during a particular time period. A 50\% KUD was used as the core activity area and a $95 \%$ KUD as the home range area (Abecasis et al. 2013b). We used $25 \times 25 \mathrm{~m}$ cell grids and a smoothing factor (h) of 250 to estimate KUD with Hawth's analysis tools for ArcGIS v.9.3. The maximum range length or dispersion along the coast was estimated as the maximum distance registered between the acoustic receivers with detections for each individual. Additionally, we calculated the percentage of days individual fish were detected by more than 1 receiver, and the maximum number of receivers where fish were detected in a single day. To test for a possible relationship between fish TL and home range (50 and 95\% KUD) or residency ( $I_{R}$ and $\left.I_{\mathrm{WR}}\right)$, we used the Pearson correlation coefficient. 


\section{RESULTS}

\section{Fish counts}

For the comparison between inside the reserve (FPA + PPAs) and outside the reserve area (BA), average log response ratios of density and biomass were significantly different from the expected null hypothesis of zero, with the ratios and respective $95 \% \mathrm{CI}$ limits being greater than zero. This means both density and biomass are significantly higher inside than outside the reserve for legal-sized white seabream. Conversely, the comparison between FPA and PPA revealed log response ratios and corresponding 95\% CI limits not significantly different from zero, for both density and biomass.

The back transformed (from logarithm) density and biomass ratios were respectively $\sim 2$ and 1.8 times higher inside (FPA + PPA) than outside (BA), with the latter having a higher associated variability (Fig. 2). Although not significantly different, a slightly higher

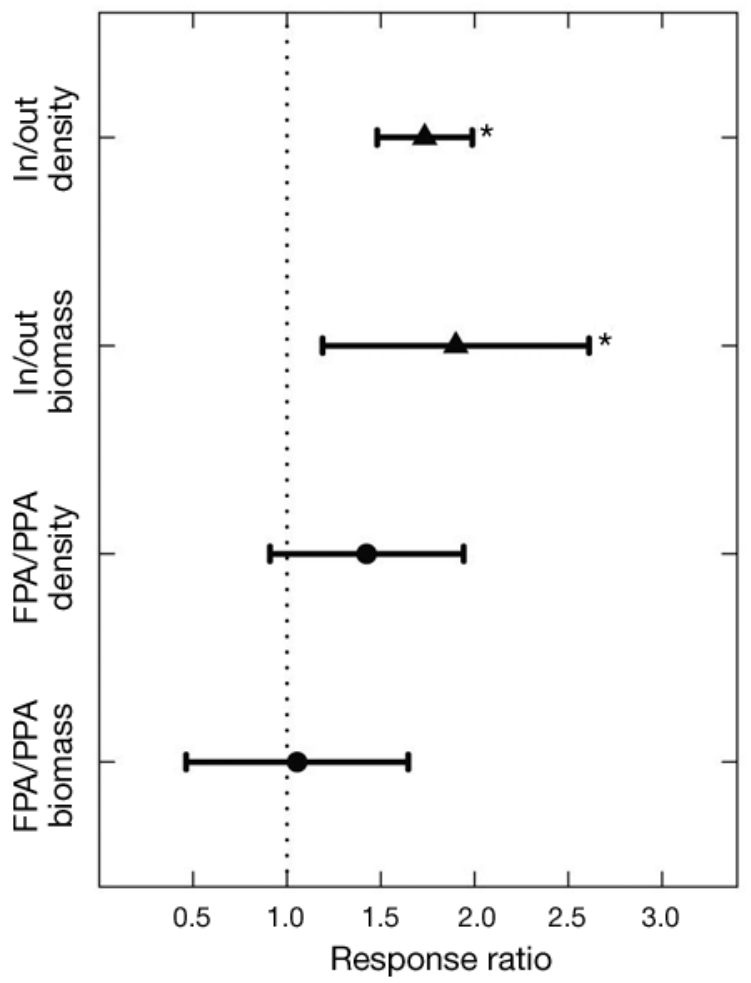

Fig. 2. Response ratios $( \pm \mathrm{SE})$ of legal-sized white seabream Diplodus sargus in the Luiz Saldanha Marine Park relative to inside or outside (In/Out) the fully protected area (FPA) and partially protected areas (PPAs) inside the reserve showing In/Out (black triangles) density (no. $\mathrm{m}^{-2}$ ) and biomass $\left(\mathrm{g} \mathrm{m}^{-2}\right)$ and FPA/PPA density and biomass (black circles). Ratios greater than 1 indicate that response variables are higher inside the reserve relative to outside or inside the FPA relative to PPA. Significant ratios are indicated with * density was observed in the FPA when compared to PPA, whereas the biomass ratio was almost one $(\sim 1.1)$, indicating very similar fish biomasses in these 2 areas.

\section{Acoustic telemetry}

The detection period of tagged white seabreams (i.e. the time span between the first and last detections) ranged between 2 and 293 d (Mean $\pm \mathrm{SE}=$ $151.5 \pm 108.7 \mathrm{~d}$ ) with 11 fish being detected for more than $90 \%$ of the expected battery lifetime (Fig. 3). No data analysis were performed for the 4 fish with less than 100 detections except for estimation of their maximum range. KUDs were only estimated for the 14 fish detected at more than 1 receiver and with a total number of detections above 500. The majority of individuals showed residency values above $0.6\left(I_{\mathrm{WR}}\right.$, Table 1). Additionally, two-thirds of the tagged fish also showed the highest local $I_{\mathrm{R}}$ in the receiver located closest to their tagging location (Table 2).

The individual displacement along the coast, or maximum range length detected, was also short, with most fish apparently staying within a stretch of coastline around $2 \mathrm{~km}$ in length even though other receivers were located further away. Of the 15 fish that were analysed, 8 were detected by more than 1 receiver in more than half of the monitored days (Table 1). Only 2 fish (Fish 5 and 8) were detected on 10 or more receivers corresponding to a stretch of coastline around $5 \mathrm{~km}$ in length, with Fish 5 being detected by 11 receivers in a single day (Table 1).

The $95 \%$ KUDs ranged between 0.43 and $1.56 \mathrm{~km}^{2}$ (average $=0.77 \pm 0.39 \mathrm{~km}^{2}$ ), meaning that the size of the reserve is between 7 and 25 times the size of home range areas (Fig. 4). The $50 \%$ KUDs ranged between 0.13 and $0.41 \mathrm{~km}^{2}$ (Table 1 ). We found a significant positive correlation between TL and maximum range length (Pearson's $r=0.48, p=0.044$ ) and between fish TL and $I_{\mathrm{WR}}$ (Pearson's $\mathrm{r}=0.45, \mathrm{p}=0.048$ ) (Fig. 5). No significant correlations were found between TL and $50 \%$ KUD, $95 \%$ KUD or $I_{R}$ (Fig. 6).

\section{DISCUSSION}

The results of this study suggest that even small, recently established coastal marine reserves can increase the abundance and biomass of commercial fish species such as white seabream, provided target species have small home ranges and high site fidelity. Our results are supported by a previous 


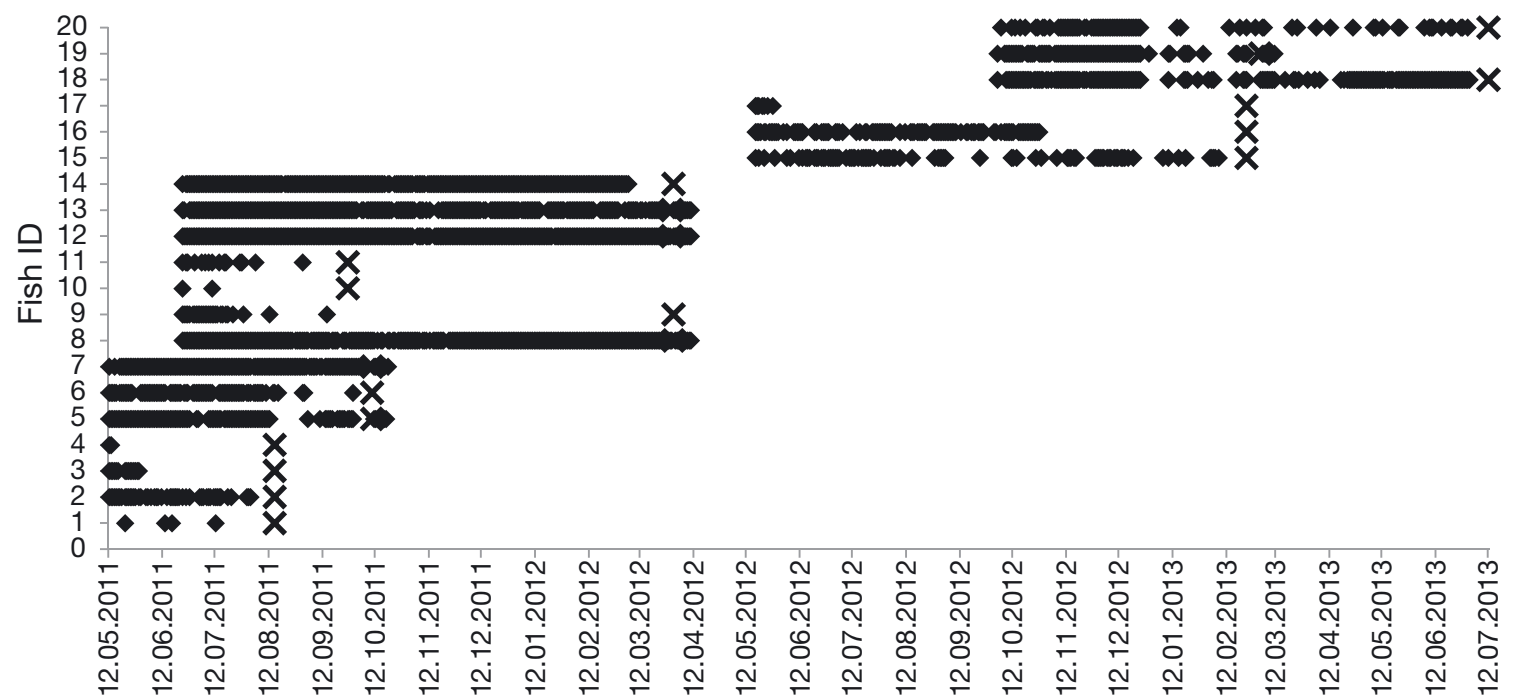

Fig. 3. Diplodus sargus. Calendar plot showing the daily detections of white seabream fitted with acoustic transmitters in the Luiz Saldanha Marine Park, Portugal. The ' $x$ ' signals the end of the estimated lifetime of the tag. Dates are dd.mm.yyyy

Table 1. Summary data for tagged white seabream. TL: total length $(\mathrm{cm}) ; D_{\mathrm{d}}$ : days with detections; $D_{i}$ : days between 1 st and last detection; KUD 50\%: $50 \%$ kernel utilization distribution $\left(\mathrm{km}^{2}\right)$ corresponding to core utilization area; KUD $95 \%$ : $95 \%$ kernel utilization distribution corresponding to home range area; $I_{\mathrm{R}}$ : residency index; $I_{\mathrm{WR}}$ : weighted residency index; RD: percentage of days with detections by more than 1 receiver, with the maximum number of receivers with detections in one day shown in brackets. -: parameter was not calculated due to low number of detections

\begin{tabular}{|c|c|c|c|c|c|c|c|c|c|c|c|c|c|}
\hline ID & TL & $\begin{array}{c}\text { Tagging } \\
\text { (dd.mm. } \\
\text { уууy) }\end{array}$ & $D_{\mathrm{d}}$ & $D_{i}$ & $\begin{array}{c}\text { Tag } \\
\text { life- } \\
\text { time (d) }\end{array}$ & $\begin{array}{l}\text { Trans- } \\
\text { mission } \\
\text { rate (d) }\end{array}$ & $\begin{array}{c}\text { Detec- } \\
\text { tions }\end{array}$ & $\begin{array}{c}\text { Maximum } \\
\text { range } \\
(\mathrm{km})\end{array}$ & $\begin{array}{l}\text { KUD } \\
95 \%\end{array}$ & $\begin{array}{l}\text { KUD } \\
50 \%\end{array}$ & $I_{\mathrm{R}}$ & $I_{\mathrm{WR}}$ & $\begin{array}{l}\mathrm{RD} \\
(\%)\end{array}$ \\
\hline 1 & 23 & 12.05 .2011 & 4 & 62 & 95 & $30-90$ & 4 & $-^{\mathrm{a}}$ & - & - & - & - & - \\
\hline 2 & 21 & 12.05 .2011 & 50 & 82 & 95 & $30-90$ & 476 & 3.2 & - & - & 0.61 & 0.45 & $26(3)$ \\
\hline 3 & 20 & 12.05 .2011 & 15 & 18 & 95 & $30-90$ & 1015 & $-{ }^{a}$ & - & - & - & - & - \\
\hline 4 & 23 & 12.05 .2011 & 2 & 2 & 95 & $30-90$ & 20 & 2.1 & - & - & - & - & - \\
\hline 5 & 37 & 12.05 .2011 & 108 & 160 & 151 & $15-45$ & 32600 & 5.0 & 1.28 & 0.21 & 0.68 & 0.76 & $49(11)$ \\
\hline 6 & 29 & 12.05 .2011 & 81 & 141 & 151 & $15-45$ & 12281 & 1.6 & 0.59 & 0.18 & 0.57 & 0.50 & $73(3)$ \\
\hline 7 & 26 & 12.05 .2011 & 149 & 161 & 151 & $15-45$ & 20832 & 1.6 & 0.43 & 0.13 & 0.93 & 1.05 & $53(3)$ \\
\hline 8 & 23 & 23.06 .2011 & 276 & 293 & 282 & $30-90$ & 15659 & 4.5 & 0.99 & 0.25 & 0.94 & 1.02 & $80(6)$ \\
\hline 9 & 29 & 23.06 .2011 & 28 & 36 & 282 & $30-90$ & 5315 & 1.6 & 0.50 & 0.14 & 0.78 & 0.01 & $61(4)$ \\
\hline 10 & 22 & 23.06 .2011 & 2 & 18 & 95 & $30-90$ & 3 & 0.8 & - & - & - & - & - \\
\hline 11 & 20 & 23.06 .2011 & 15 & 70 & 95 & $30-90$ & 25 & 1.1 & - & - & - & - & - \\
\hline 12 & 24 & 23.06 .2011 & 286 & 293 & 282 & $30-90$ & 17634 & 2.1 & 0.45 & 0.13 & 0.98 & 1.05 & $52(5)$ \\
\hline 13 & 30 & 23.06 .2011 & 253 & 293 & 282 & $30-90$ & 10624 & 2.1 & 0.52 & 0.13 & 0.86 & 0.93 & $34(4)$ \\
\hline 14 & 29 & 23.06 .2011 & 250 & 257 & 282 & $30-90$ & 16719 & 2.7 & 0.46 & 0.13 & 0.97 & 0.81 & $70(6)$ \\
\hline 15 & 24 & 17.05 .2012 & 90 & 267 & 282 & $30-90$ & 2824 & 1.5 & 0.57 & 0.14 & 0.34 & 0.30 & $11(2)$ \\
\hline 16 & 22 & 17.05 .2012 & 104 & 164 & 282 & $30-90$ & 4302 & 1.6 & 0.50 & 0.13 & 0.63 & 0.21 & $47(4)$ \\
\hline 17 & 24 & 17.05 .2012 & 7 & 11 & 282 & $30-90$ & 558 & 1.4 & 0.67 & 0.17 & 0.64 & 0.00 & 57 (3) \\
\hline 18 & 29 & 03.10 .2012 & 173 & 272 & 282 & $30-90$ & 18171 & 3.7 & 1.56 & 0.41 & 0.64 & 0.64 & $62(7)$ \\
\hline 19 & 27 & 03.10 .2012 & 96 & 160 & 151 & $15-45$ & 14025 & 3.7 & 1.45 & 0.26 & 0.60 & 0.67 & $43(8)$ \\
\hline 20 & 26 & 03.10 .2012 & 82 & 271 & 282 & $30-90$ & 2041 & 2.1 & 0.76 & 0.17 & 0.30 & 0.30 & $12(3)$ \\
\hline
\end{tabular}

study in the same MPA, where rocky reef fish assemblages were assessed and different sources of data were combined, indicating an early reserve effect for commercial demersal species (legal-sized; Horta e Costa et al. 2013b). In that study, differences in biomass but not in density were found between the reserve and fished areas for demersal legal-sized commercial fish, and they were not related to habitat features. A comparison between before and after the establishment of protection measures was also conducted, but 'before' data consisted only of density (with all sizes aggregated as length estimation was 
Table 2. Individual residency index $\left(I_{R}\right)$ for each tagged white seabream and each acoustic receiver. Values in bold denote the receiver closest to the tagging location. Fish 1, 3, 4, 10 and 11 had fewer than 100 detections. The value 0.00 means that fish were detected by that receiver but the $I_{\mathrm{R}}$ was less than 0.01 . TL: total length

\begin{tabular}{|c|c|c|c|c|c|c|c|c|c|c|c|c|}
\hline \multirow[t]{2}{*}{ ID } & \multirow{2}{*}{$\begin{array}{l}\mathrm{TL} \\
(\mathrm{cm})\end{array}$} & \multirow[b]{2}{*}{ A } & \multirow[b]{2}{*}{ B } & \multirow[b]{2}{*}{$\mathrm{C}$} & \multirow[b]{2}{*}{$\mathrm{D}$} & \multicolumn{3}{|c|}{ Acoustic receiver } & \multirow[b]{2}{*}{$\mathrm{H}$} & \multirow[b]{2}{*}{ I } & \multirow[b]{2}{*}{$\mathrm{J}$} & \multirow[b]{2}{*}{$\mathrm{K}$} \\
\hline & & & & & & E & $\mathrm{F}$ & G & & & & \\
\hline 1 & 23 & & & & & & & & & & & \\
\hline 2 & 21 & & & 0.02 & 0.01 & 0.01 & 0.01 & 0.04 & 0.26 & 0.44 & & \\
\hline 3 & 20 & & & & & & & & & & & \\
\hline 4 & 23 & & & & & & & & & & & \\
\hline 5 & 37 & 0.06 & 0.09 & 0.17 & 0.20 & 0.66 & 0.28 & 0.13 & 0.05 & 0.04 & 0.03 & 0.01 \\
\hline 6 & 29 & & & 0.04 & 0.47 & 0.52 & & & & & & \\
\hline 7 & 26 & & & 0.02 & 0.93 & 0.48 & & & & & & \\
\hline 8 & 23 & 0.00 & 0.00 & 0.05 & 0.07 & 0.80 & 0.83 & 0.14 & 0.01 & 0.01 & 0.01 & \\
\hline 9 & 29 & & & & & 0.18 & 0.29 & 0.24 & 0.01 & & & \\
\hline 10 & 22 & & & & & & & & & & & \\
\hline 11 & 20 & & & & & & & & & & & \\
\hline 12 & 24 & & & & & & 0.49 & 0.97 & 0.03 & 0.01 & 0.02 & \\
\hline 13 & 30 & & & & & & 0.26 & 0.85 & 0.11 & 0.01 & 0.01 & \\
\hline 14 & 29 & & & 0.02 & 0.02 & 0.02 & 0.15 & 0.73 & 0.92 & & & \\
\hline 15 & 23.5 & & & & & & & & 0.28 & 0.80 & 0.03 & \\
\hline 16 & 22 & & & & & & 0.04 & 0.47 & 0.97 & 0.06 & & \\
\hline 17 & 24 & & & & & 0.86 & 0.71 & 0.29 & & & & \\
\hline 18 & 29 & & & 0.39 & 0.40 & 0.40 & 0.51 & 0.62 & 0.42 & 0.16 & 0.05 & \\
\hline 19 & 26.5 & & & 0.41 & 0.40 & 0.28 & 0.36 & 0.36 & 0.68 & 0.03 & 0.02 & \\
\hline 20 & 25.8 & & & & & & 0.13 & 0.17 & 0.65 & 0.15 & 0.04 & \\
\hline
\end{tabular}

home range areas do not seem to increase with fish size, this spillover of larger individuals can be limited.

Another interesting finding of this study is that there were no significant differences in abundance or biomass of white seabream between the FPA and the PPAs, supporting the adequacy of this reserve design for rocky reef fish species. Commercial fish species associated with the narrow rocky habitat found nearshore and showing high site fidelity are expected to be protected from fisheries both in the FPA and PPAs, since in the PPAs fishing is only allowed beyond $200 \mathrm{~m}$ offshore and only using fishing gears targeting cephalopods (jigs and traps). As we found here, previous experimental fishing trials in the area also suggested that white seabream do not range far from the nearshore rocky bottoms

not done, preventing the classification of fish from above or below legal sizes and the estimation of biomasses) and from sites currently inside the reserve, so a true BACI design was not possible. Despite not being significant, density of the most targeted species (all sizes) revealed some increase inside the reserve when compared to the 'before' period. Furthermore, landings of most commercial species have shown an increase over time, suggesting that at the very least, protection measures have not had negative impacts on local fisheries (see Horta e Costa et al. 2013b for details). The present study aimed at understanding if the positive responses of the highly commercial white seabream could in part be due to small home ranges and high site fidelity. In fact, our study helps to explain the early reserve effect on this species and possibly on other species with similar spatio-temporal dynamics.

Our results showed high site fidelity and home range areas about 14 times smaller than the protected area, reducing the vulnerability to fishing (Moffitt et al. 2009, Abecasis et al. 2014b), which in turn may explain the significantly higher biomass and densities found inside the reserve when compared to fished areas. In addition, larger fish seem to roam over larger distances, which can lead to spillover into unprotected areas. Nevertheless, because
(Cunha et al. 2011), and an earlier telemetric study elsewhere also reported a preference of white seabream for rocky bottoms (Abecasis et al. 2013b). In the case of our study site, the PPAs surrounding the FPA significantly increase the contiguous area where white seabream and other species with similar habits are protected. Thus, the total amount of coastline where reef fishes are protected from fishing in the LSMP is around $20 \mathrm{~km}$, which is 8.5 times the average maximum range length of local adult white seabream. The contiguity of protection of essential habitat for adults, including their daily and seasonal movements, allows a permanent refuge from fishing mortality and, thus, the opportunity for higher survival and growth (Kramer \& Chapman 1999, Russ 2002, Huserbråten et al. 2013). This likely explains the significantly larger biomass of legal-sized white seabream inside the reserve when compared to the neighbouring fished areas.

Our results are similar to the findings of other studies reporting that even small areas protected from fishing for even a few years can build up spawning biomass of some commercial species, likely leading to an exponential increase in fecundity and to population persistence (Russ 2002, Pelc et al. 2010, Fraschetti et al. 2011). This is particularly important for highly valuable commercial species targeted by 
응
은
은
른
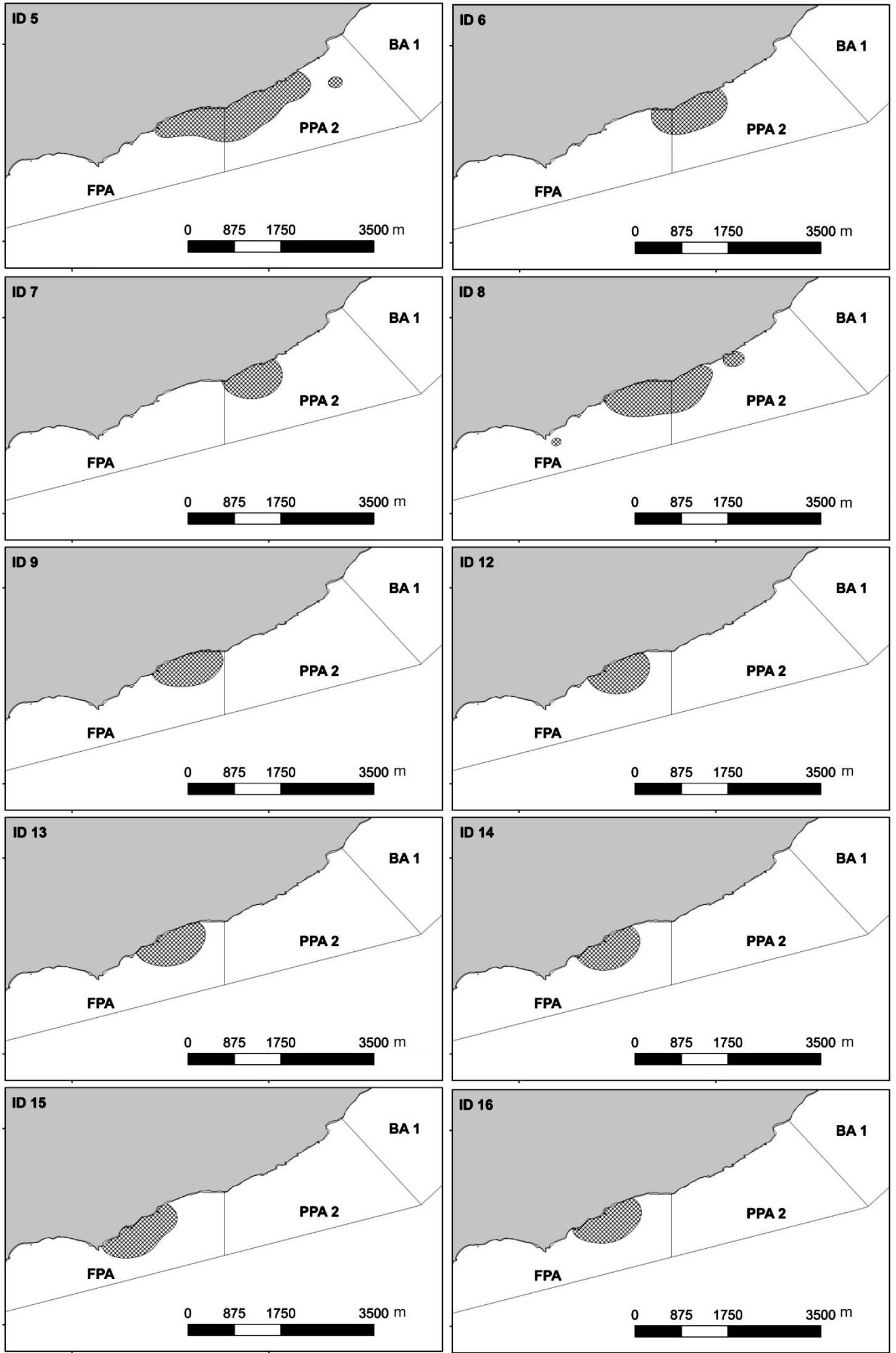

Fig. 4 (continued on next page) 

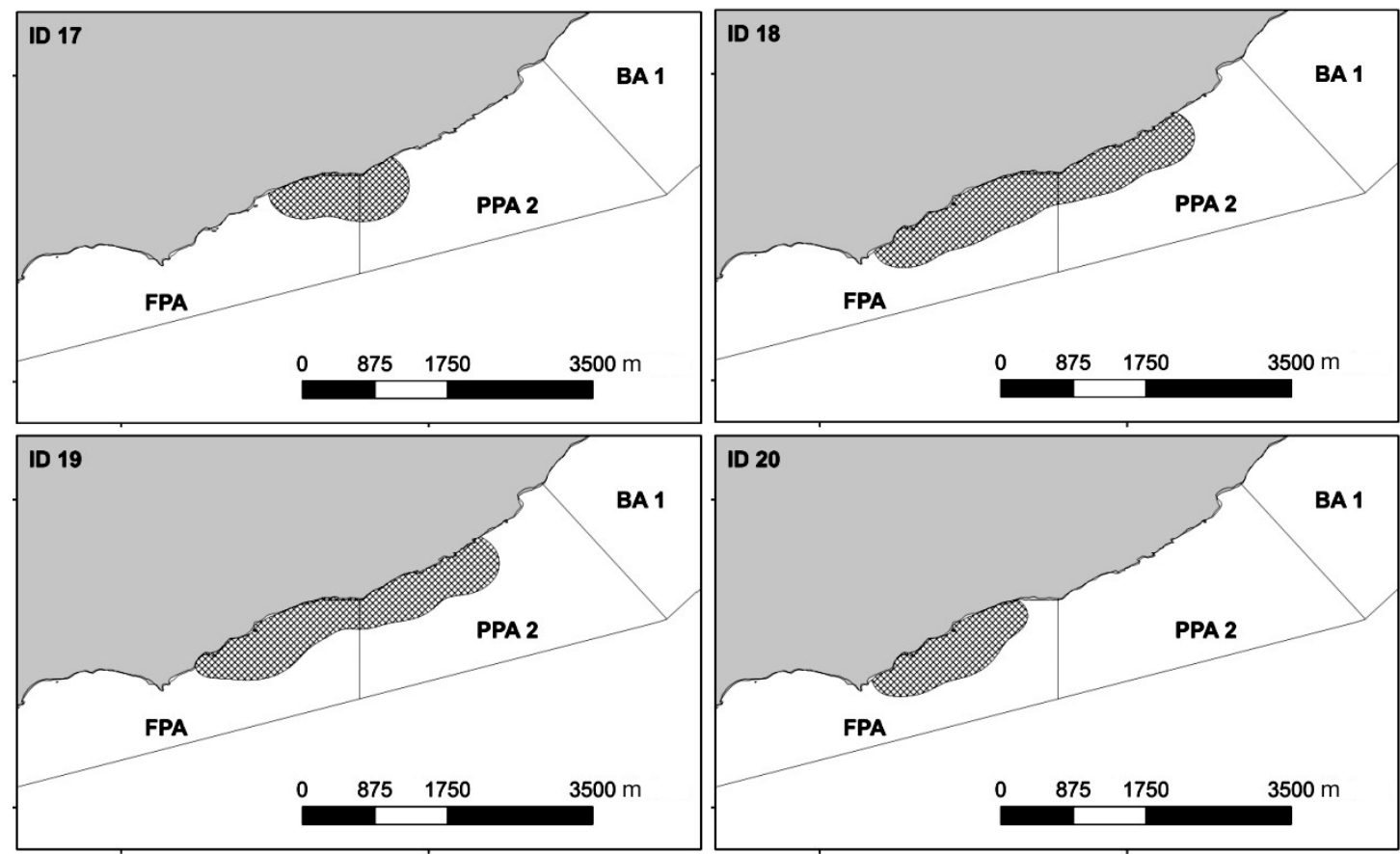

Fig. 4. Diplodus sargus. Home range areas for 14 white seabream tagged with acoustic transmitters showing the $95 \%$ kernel utilization distribution (KUD), represented by the crosshatched areas. FPA: fully protected area; PPA: partially protected area; BA: buffer area

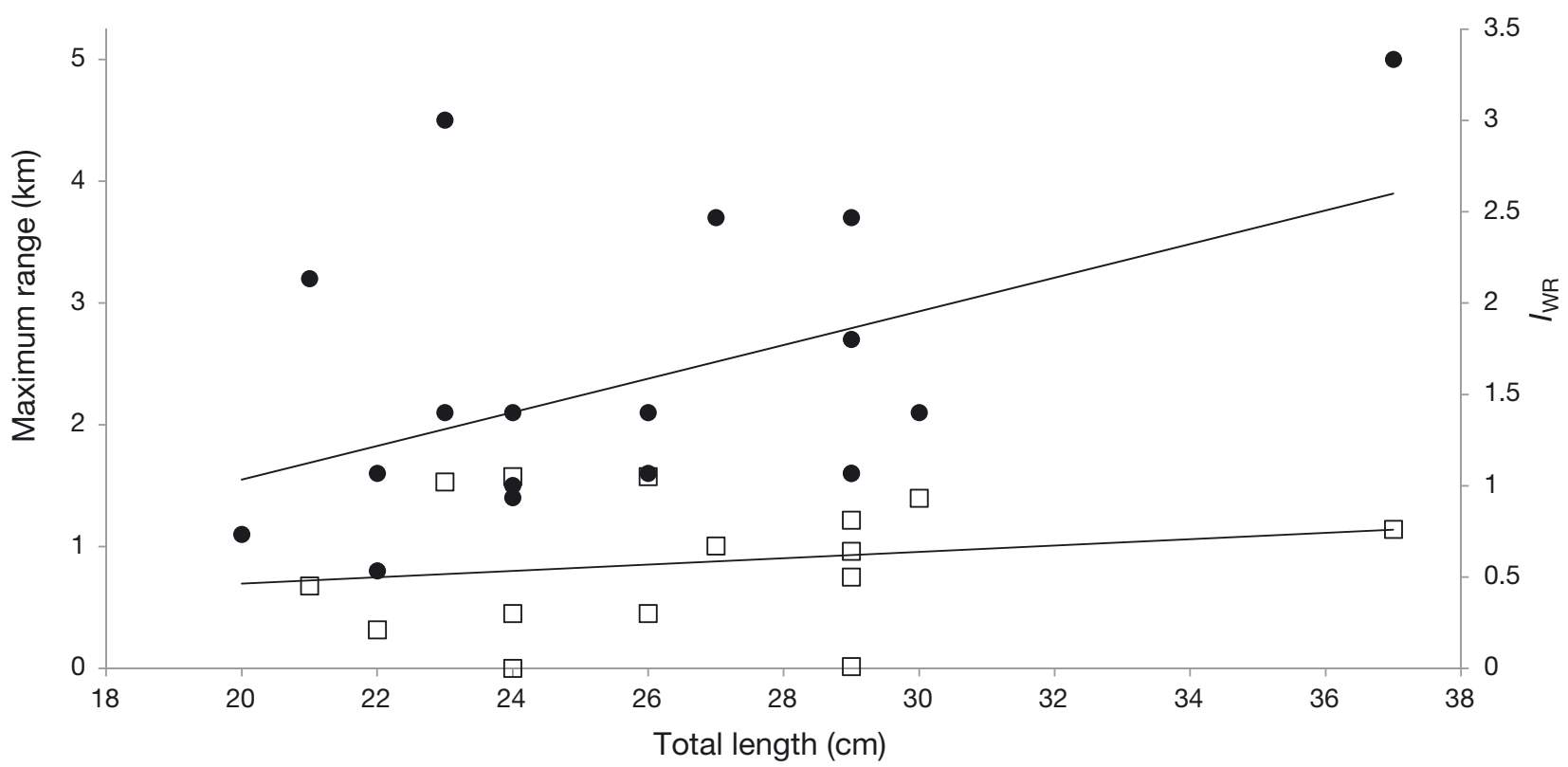

Fig. 5. Diplodus sargus. Relationship between total length (TL, $\mathrm{cm})$ and maximum range (km) (black circles) and between TL and weighted residency index $\left(I_{\mathrm{WR}}\right)$ (open squares). Significant correlations were found: TL vs. maximum range $($ Pearson's $\mathrm{r}=$ $0.48, \mathrm{p}=0.044)$ and TL vs. $I_{\mathrm{WR}}($ Pearson's $\mathrm{r}=0.45, \mathrm{p}=0.048)$

small-scale fisheries, which is the case for most coastal multiple-use MPAs where artisanal fisheries prevail, as in this study. These results also underpin the importance of an appropriate design and zoning of a MPA to deliver specific objectives, which may vary with local ecological and socio-economic features and depend on the species and habitats they intend to protect and manage. The LSMP, and other 


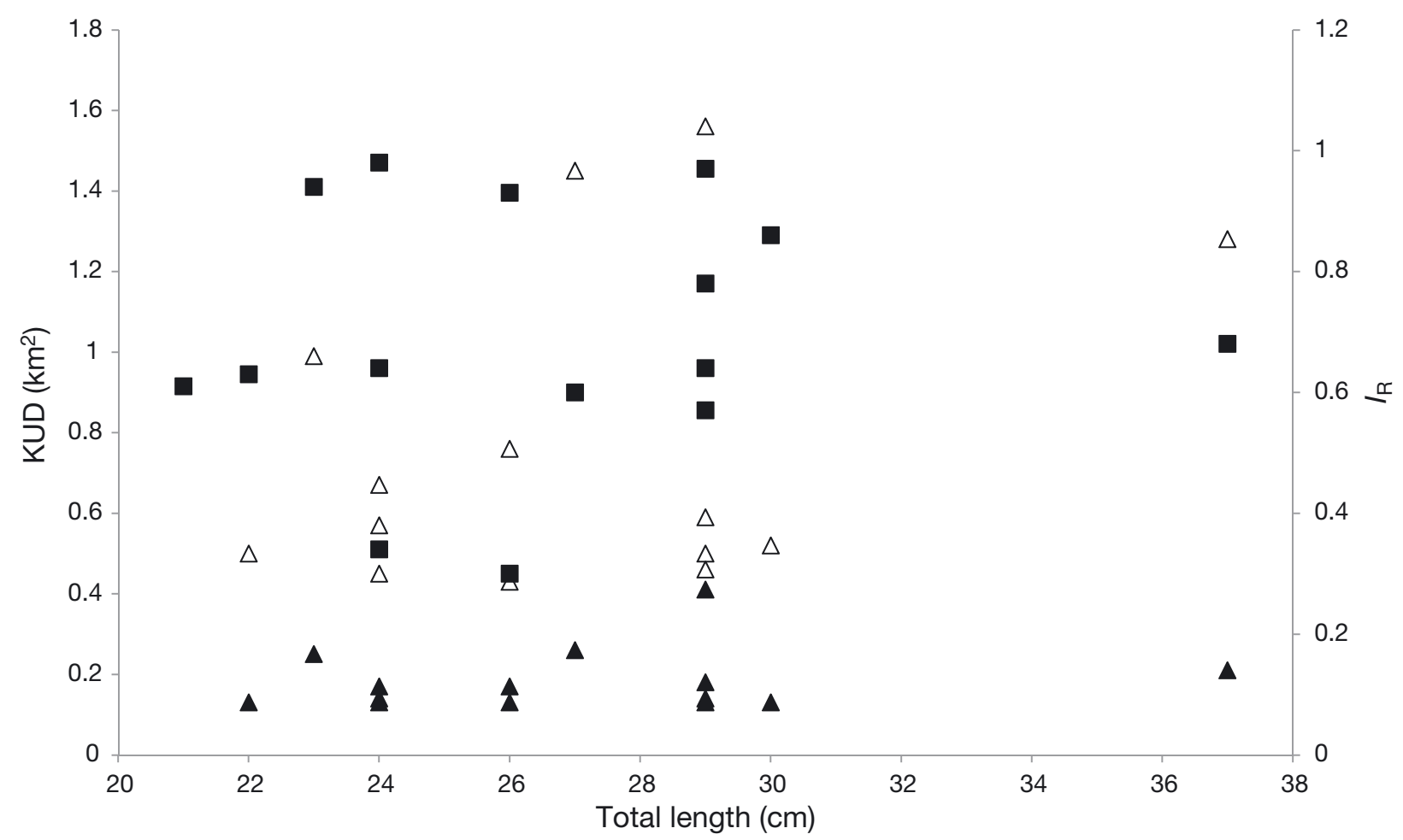

Fig. 6. Diplodus sargus. Relationship between total length (TL, cm) and 95\% kernel utilization distribution (KUD, km $\left.{ }^{2}\right)$ in open triangles, between TL and $50 \%$ KUD (black triangles) and between TL and residency index $\left(I_{\mathrm{R}}\right)$ (black squares). No significant correlations were found

small reserves in temperate regions, can therefore play an important role in the local management of this species and of other rocky reef fish species with similar home ranges.

Moreover, our results also highlight the increasingly recognized role of PPAs in meeting conservation and fisheries goals of MPAs. They are often easier to implement than no-take areas, since by allowing some activities, fewer conflicts among local users arise (Lester \& Halpern 2008). PPAs can still meet conservation goals when properly designed and placed (Floeter et al. 2006, Sciberras et al. 2013). The PPAs in our study area increase the total continuous area where rocky reef species are protected, and thus are likely to protect marine species associated with rocky reefs, especially those with smaller home ranges. However, in the soft bottoms beyond $200 \mathrm{~m}$ offshore, and thus in the majority of their areas, PPAs are open to some fisheries. Numerous commercial species occur on soft bottoms and are targeted either by nets (e.g. skates, soles) in the BAs or by traps and jigs (e.g. octopus, cuttlefish and squid) in the BAs and PPAs. These species usually have larger home ranges or seasonal migrations (Batista et al. 2009, Abecasis et al. 2013a, 2014a, Horta e Costa et al. 2013c), meaning that full protection inside the FPA or in the no fishing zone $(<200 \mathrm{~m})$ of the PPAs surrounding it is not likely to occur, reducing the conservation role of this marine park for these species. Therefore, multiple-use MPAs with this type of zoning based in small areas with different levels of protection are not expected to drive positive reserve effects for a wide range of species, especially those more mobile, as previously shown for cuttlefish in this MPA (Abecasis et al. 2013a).

The different responses of commercial species to the implementation of PPAs highlight the importance of the ongoing debate about the performance of multiple-use MPAs and, in particular, of PPAs. Globally and over time, reserve effects have been demonstrated in numerous studies and reviews (Halpern 2003, Claudet et al. 2008, Lester et al. 2009, Hamilton et al. 2010), but the effects of PPAs are less well known (Sciberras et al. 2013), especially due to the diversity of management rules in PPAs and their various ecological and socio-economic objectives.

Although several studies have been published on the movement patterns, home range and site fidelity of white seabream (e.g. Abecasis et al. 2009, 2013b, D'Anna et al. 2011), the differences observed be- 
tween them support the need for validation of these metrics at local sites, especially when MPAs are concerned. The average size of the home range areas found in this study is less than half of the average size found by Abecasis et al. (2013b) for white seabream in the South of Portugal. One reason for this could be habitat differences, since that study took place in a set of artificial and natural reefs surrounded by sandy bottoms whereas the current study took place in a stretch of rocky coastline that extends for over $20 \mathrm{~km}$, providing plenty of refuges. Another non-exclusive hypothesis is related to differences in prey availability. Larger reef areas in the LSMP compared with the study area of Abecasis et al. (2013b) probably offer greater abundance and variety of prey.

The fact that this study took place in a marine reserve may also explain some of the differences found between the home range areas obtained in this study and those obtained in other locations. A study on another related fish species, the sparid Pagrus auratus (Parsons et al. 2010), showed differences in home range size between individuals studied inside and outside the reserve. Parsons et al. (2010) suggest that fish with small home ranges centred within the reserve will not cross the reserve boundaries often, and will therefore be less likely to be captured by fishing. This would lead to a different selection pressure favouring individuals with smaller home range areas, possibly increasing their probabilities of producing offspring when compared to more mobile individuals crossing reserve boundaries that will bear lower survivorship and reproductive potential (Parsons et al. 2010, Olsen et al. 2012, Wiig et al. 2013). Although some selective survival is possibly occurring by decreasing or removing fishing mortality for less mobile species within the reserve, given the young age of the LSMP, it is very unlikely that such an inter-generational effect is already producing noticeable effects in the local population dynamics. Nevertheless, future studies should investigate this possibility.

Studies combining the ecological responses to protection measures with observed behavioural aspects of marine species, such as movement patterns and habitat use, are of major importance to understand MPA performance and species responses (Huserbråten et al. 2013, Moland et al. 2013). In this study, we measured the positive responses of white seabream in a multiple-use coastal MPA by studying their site fidelity, home range and changes in density and biomass. The present work adds valuable information to the management of commercial demersal species in the context of MPAs.
Acknowledgements. We are grateful to the Biomares team for their help with acoustic receiver deployment and retrieval. We thank J. E. Caselle for comments and English revision of this manuscript. We are also grateful to the anonymous reviewers for their valuable contributions. This research was partially funded by the ERA-Net BiodivERsA project 'BUFFER - Partially protected areas as buffers to increase the linked social-ecological resilience', with the national funders ANR (France), FCT (Portugal), FORMAS (Sweden), SEPA (Sweden) and RCN (Norway), part of the 2011-2012 BiodivERsA joint call for research proposals, by the Pluriannual Program (R\&D Unit 331/94, PEst-OE/ MAR/UI0331/2011), and by the EU LIFE-BIOMARES Project (LIFE06 NAT/P/000192). D.A. and B.H.C. acknowledge financial support by the Portuguese Foundation for Science and Technology/Ministry of Education and Science (FCT/ MCTES-MEC) through individual $\mathrm{PhD}$ grants (SFRH/ BD/46286/2008 and SFRH/BD/41262/2007).

\section{LITERATURE CITED}

Abecasis D, Erzini K (2008) Site fidelity and movements of gilthead sea bream (Sparus aurata) in a coastal lagoon (Ria Formosa, Portugal). Estuar Coast Shelf Sci 79:758-763

Abecasis D, Bentes L, Coelho R, Correia C and others (2008) Ageing seabreams: a comparative study between scales and otoliths. Fish Res 89:37-48

Abecasis D, Bentes L, Erzini K (2009) Home range, residency and movements of Diplodus sargus and Diplodus vulgaris in a coastal lagoon: connectivity between nursery and adult habitats. Estuar Coast Shelf Sci 85:525-529

Abecasis D, Bentes L, Erzini K (2012) Movements of Sarpa salpa (Linnaeus, 1758) (Sparidae) in a coastal lagoon (Ria Formosa, Portugal). J Appl Ichthyology 28:126-129

Abecasis D, Afonso P, O'Dor RK, Erzini K (2013a) Small MPAs do not protect cuttlefish (Sepia officinalis). Fish Res 147: 196-201

> Abecasis D, Bentes L, Lino PG, Santos MN, Erzini K (2013b) Residency, movements and habitat use of adult white sea bream (Diplodus sargus) between natural and artificial reefs. Estuar Coast Shelf Sci 118:80-85

Abecasis D, Afonso P, Erzini K (2014a) Can small MPAs protect local populations of a coastal flatfish, Solea senegalensis? Fish Manag Ecol 21:175-185

Abecasis D, Afonso P, Erzini K (2014b) Combining multispecies home range and distribution models aids assessment of MPA effectiveness. Mar Ecol Prog Ser 513: $155-169$

> Afonso P, Fontes J, Holland KN, Santos RS (2008) Social status determines behaviour and habitat usage in a temperate parrotfish: implications for marine reserve design. Mar Ecol Prog Ser 359:215-227

Babcock RC, Egli DP, Attwood CG (2012) Incorporating behavioural variation in individual-based simulation models of marine reserve effectiveness. Environ Conserv 39: 282-294

Batista MI, Teixeira CM, Cabral HN (2009) Catches of target species and bycatches of an artisanal fishery: the case study of a trammel net fishery in the Portuguese coast. Fish Res 100:167-177

Botsford LW, Micheli F, Hastings A (2003) Principles for the design of marine reserves. Ecol Appl 13(Suppl):S25-S31

Botsford L, Brumbaugh D, Grimes C, Kellner J and others (2009) Connectivity, sustainability, and yield: bridging the gap between conventional fisheries management and marine protected areas. Rev Fish Biol Fish 19:69-95 
Claudet J, Osenberg CW, Benedetti-Cecchi L, Domenici P and others (2008) Marine reserves: Size and age do matter. Ecol Lett 11:481-489

Claudet J, Osenberg CW, Domenici P, Badalamenti F and others (2010) Marine reserves: Fish life history and ecological traits matter. Ecol Appl 20:830-839

Cunha A, Erzini K, Serrão E, Gonçalves E and others (2011) Restoration and management of biodiversity in the marine park site Arrábida-Espiche (PTCON0010). Biomares Project No. LIFE06 NAT/P/000192 final report, Centro de Ciências do Mar, Universidade do Algarve, Faro

- D'Anna G, Giacalone VM, Pipitone C, Badalamenti F (2011) Movement pattern of white seabream, Diplodus sargus (L., 1758) (Osteichthyes, Sparidae) acoustically tracked in an artificial reef area. Ital J Zool 78:255-263

> Floeter SR, Halpern BS, Ferreira CEL (2006) Effects of fishing and protection on Brazilian reef fishes. Biol Conserv 128: 391-402

Fraschetti S, Claudet J, Grorud-Colvert K (2011) Transitioning from single-sector management to ecosystem-based management: What can marine protected areas offer? In: Claudet J (ed) Marine protected areas: a multidisciplinary approach. Cambridge University Press, Cambridge, p 11-34

> Gonçalves JMS, Bentes L, Lino PG, Ribeiro J, Canário AVM, Erzini K (1997) Weight-length relationships for selected fish species of the small-scale demersal fisheries of the south and south-west coast of Portugal. Fish Res 30:253-256

Grüss A, Kaplan DM, Guénette S, Roberts CM, Botsford LW (2011) Consequences of adult and juvenile movement for marine protected areas. Biol Conserv 144:692-702

> Halpern BS (2003) The impact of marine reserves: Do reserves work and does reserve size matter? Ecol Appl 13:117-137

> Hamilton SL, Caselle JE, Malone DP, Carr MH (2010) Incorporating biogeography into evaluations of the Channel Islands marine reserve network. Proc Natl Acad Sci USA 107:18272-18277

> Horta e Costa B, Batista MI, Gonçalves L, Erzini K, Caselle JE, Cabral HN, Gonçalves EJ (2013a) Fishers' behaviour in response to the implementation of a marine protected area. PLoS ONE 8:e65057

> Horta e Costa B, Erzini K, Caselle JE, Folhas H, Gonçalves EJ (2013b) 'Reserve effect' within a temperate marine protected area in the north-eastern Atlantic (Arrábida Marine Park, Portugal). Mar Ecol Prog Ser 481:11-24

- Horta e Costa B, Gonçalves L, Gonçalves EJ (2013c) Vessels' site fidelity and spatio-temporal distribution of artisanal fisheries before the implementation of a temperate multiple-use marine protected area. Fish Res 148:27-37

> Huserbråten MBO, Moland E, Knutsen H, Olsen EM, André C, Stenseth NC (2013) Conservation, spillover and gene flow within a network of northern European Marine Protected Areas. PLoS ONE 8:e73388

Koeck B, Alós J, Caro A, Neveu R, Crec'hriou R, Saragoni G, Lenfant P (2013) Contrasting fish behavior in artificial seascapes with implications for resources conservation. PLoS ONE 8:e69303

Kramer DL, Chapman MR (1999) Implications of fish home range size and relocation for marine reserve function. Environ Biol Fishes 55:65-79

> Lester SE, Halpern BS (2008) Biological responses in marine no-take reserves versus partially protected areas. Mar Ecol Prog Ser 367:49-56

Lester SE, Halpern BS, Grorud-Colvert K, Lubchenco J and others (2009) Biological effects within no-take marine reserves: a global synthesis. Mar Ecol Prog Ser 384:33-46

Lino PG, Bentes L, Abecasis D, Santos MN, Erzini K (2009)
Comparative behavior of wild and hatchery reared white sea bream (Diplodus sargus) released on artificial reefs off the Algarve (Southern Portugal). In: Nielsen JL, Arrizabalaga H, Fragoso N, Hobday A, Lutcavage M, Sibert J (eds) Methods and technologies in fish biology and fisheries, No. 9. Tagging and tracking of marine animals with electronic devices. Springer, Dordrecht, p 23-34

Meyer CG, Holland KN (2005) Movement patterns, home range size and habitat utilization of the bluespine unicornfish, Naso unicornis (Acanthuridae) in a Hawaiian marine reserve. Environ Biol Fishes 73:201-210

Moffitt EA, Botsford LW, Kaplan DM, O'Farrell MR (2009) Marine reserve networks for species that move within a home range. Ecol Appl 19:1835-1847

Moland E, Olsen EM, Knutsen H, Garrigou P and others (2013) Lobster and cod benefit from small-scale northern marine protected areas: inference from an empirical before-after control-impact study. Proc R Soc Lond B Biol Sci 280: 20122679

Olsen EM, Heupel MR, Simpfendorfer CA, Moland E (2012) Harvest selection on Atlantic cod behavioral traits: implications for spatial management. Ecol Evol 2:1549-1562

Osenberg CW, Shima JS, Miller SL, Stier AC (2011) Assessing the effects of marine protected areas: confounding in space and possible solutions. In: Claudet J (ed) Marine protected areas: a multidisciplinary approach. Cambridge University Press, Cambridge, p 143-167

Parsons DM, Morrison MA, Slater MJ (2010) Responses to marine reserves: decreased dispersion of the sparid Pagrus auratus (snapper). Biol Conserv 143:2039-2048

Pelc RA, Warner RR, Gaines SD, Paris CB (2010) Detecting larval export from marine reserves. Proc Natl Acad Sci USA 107:18266-18271

R Development Core Team (2012) R: a language and environment for statistical computing. R Foundation for Statistical Computing, Vienna

Russ GR (2002) Yet another review of marine reserves as reef fisheries management tools. In: Sale PF (ed) Coral reef fishes: dynamics and diversity in a complex ecosystem. Academic Press, San Diego, CA, p 421-443

Sciberras M, Jenkins SR, Mant R, Kaiser MJ, Hawkins SJ, Pullin AS (2013) Evaluating the relative conservation value of fully and partially protected marine areas. Fish Fish, doi:10.1111/faf.12044

Simpfendorfer CA, Heupel MR, Hueter RE (2002) Estimation of short-term centers of activity from an array of omnidirectional hydrophones and its use in studying animal movements. Can J Fish Aquat Sci 59:23-32

> Tetreault I, Ambrose RF (2007) Temperate marine reserves enhance targeted but not untargeted fishes in multiple notake MPAs. Ecol Appl 17:2251-2267

> Vandeperre F, Higgins RM, Sánchez-Meca J, Maynou F and others (2011) Effects of no-take area size and age of marine protected areas on fisheries yields: a meta-analytical approach. Fish Fish 12:412-426

> Veiga P, Ribeiro J, Gonçalves JMS, Erzini K (2010) Quantifying recreational shore angling catch and harvest in southern Portugal (north-east Atlantic Ocean): implications for conservation and integrated fisheries management. J Fish Biol 76:2216-2237

Wiig JR, Moland E, Haugen TO, Olsen EM (2013) Spatially structured interactions between lobsters and lobster fishers in a coastal habitat: fine-scale behaviour and survival estimated from acoustic telemetry. Can J Fish Aquat Sci 70:1468-1476

- Worton BJ (1989) Kernel methods for estimating the utilization distribution in home-range studies. Ecology 70:164-168 